\title{
DOES LIFE MAKE MORE SENSE NOW? YOUNG PEOPLE'S LIFE PROJECTS AND THE NEW FEELING OF STABILITY IN RUSSIA
}

\author{
Joachim Otto Habeck
}

\begin{abstract}
While most inhabitants of the Russian Federation remember the 1990 s as a period of "mess", the early 2000 s are commonly being associated with economic growth, more reliable household income and a higher degree of "stability" in general. The author tries to explore in various regional settings how the political idea of "stability" articulates with young people's expectations about their future. The basis for this exploration is a twofold assumption: on the one hand, an economically more stable situation is conducive to planning one's future; on the other, a general growth of income leads to a reduction of conflicts and aggression, more tolerance and a greater potential for the expression of personal predilections. The author corroborates this hypothesis by presenting his own research findings along with evidence from other scholars' work (in the Komi Republic and adjacent Nenets Autonomous Okrug, and in Novosibirsk and its surroundings). In spite of this generally optimistic view, the author also points to new aspects of social exclusion. Furthermore, restoration of moral values and the state's strong emphasis on patriotism partially contradict the general diagnosis of increased tolerance and a higher diversity of lifestyles.
\end{abstract}

Key words: diversity of lifestyles, future, Russia, stability, tolerance, youth

\section{INTRODUCTION}

In this paper, I seek to analyse how young individuals from two different regions within the Russian Federation see their situation, think about and make plans for the future, and connect their thoughts with socio-economic tendencies in their home country. I wish to explore how such large-scale developments express themselves in young people's aspirations and biographies. The question flagged in the title, "Does life makes more sense now?" debarks from a general observation - recent economic growth in Russia - and a straightforward hypothesis: economic growth translates into increasing stability of household incomes (at least in some households), hence into a higher degree of trust in the possibility of making plans, and ultimately, into the attempt at giving 
one's future a certain goal or direction - in other words, a certain sense. In particular, the stability of household income is influential when it comes to individual and familial decisions about higher education, employment and career development.

Yet there is also another aspect of a "sensible life" that appears to derive from economic growth: one may expect that to a certain degree, an improvement in the per capita income of the society as a whole will mitigate such problems as stealing and mugging, lower the overall degree of frustration and aggression, increase the amount of leisure time (since household procurements become easier) and also the amount of money that may be spent for leisuretime consumption. A higher degree of tolerance within the society and a growing range of options of how to spend one's leisure time, I argue, lead to a diversification of subcultures and lifestyles, and thus to a growing diversity of "sensible" ways of being - in other words, a growing diversity of positively felt identities.

\section{RESEARCH DESIGN AND METHODS}

The first half of the article is based on ethnographic fieldwork that I carried out in 1998-1999 among reindeer herders in the Komi Republic and the Nenets Autonomous Okrug, and a survey $(n=255)$ that I conducted in early 2002 in the same region among indigenous and non-indigenous inhabitants of rural and urban settlements. In the second half, I refer to the findings of a larger survey $(\mathrm{n}=700)$ in Novosibirsk and its surroundings conducted by Glendinning, Pak and Popkov (2004), and some preliminary results of my fieldwork in the city of Novosibirsk since August 2005.

The ethnographic fieldwork in the Komi Republic and the Nenets Autonomous Okrug was a component of the EU-supported TUNDRA Project ("TUNdra Degradation in the Russian Arctic"). ${ }^{1}$ After an initial period in which I visited many of the reindeer-herding communities in the north of the Komi Republic, I selected one state farm (sovkhoz "Ust'-Usinskii") for longer-term participant observation. Over a period of eight months I lived with four closely related families, both in the camps in the tundra and the two villages where these families have their houses or flats. Short-term visits in 2000, 2002 and 2005 provided update information on the performance of the reindeer-herding enterprises but also on the changing fortunes of the four families, and particularly the life trajectories of the young family members (Habeck 2005).

The 2002 survey was conducted within the subsequent EU-supported Project SPICE ("Sustainable Pechora in a Changing Environment and Society"). ${ }^{2}$ Re- 
Table 1. SPICE “Workpackage 2" survey on people's perceptions of socio-economic and ecological problems in 9 settlements of the Pechora Basin with a total of 255 respondents (spring 2002).

\begin{tabular}{|c|c|c|c|c|}
\hline Settlement & $\begin{array}{l}\text { Type of } \\
\text { settlement }\end{array}$ & $\begin{array}{l}\text { Population (as } \\
\text { of } 1 \text { January } \\
2000 \text { ) } \\
\end{array}$ & $\begin{array}{l}\text { No. of respondents } \\
\text { (spring 2002) }\end{array}$ & $\begin{array}{l}\text { Percentage of } \\
\text { respondents } \\
\text { among inhabitants }\end{array}$ \\
\hline Narian-Mark & $\begin{array}{l}\text { urban } \\
\text { (gorod) }\end{array}$ & 25,500 & 33 & $0.13 \%$ \\
\hline Krasnoe & $\begin{array}{l}\text { rural } \\
\text { (poselok) }\end{array}$ & 1,645 & 22 & $1.34 \%$ \\
\hline Usinsk & $\begin{array}{l}\text { urban } \\
\text { (gorod) }\end{array}$ & 47,700 & 33 & $0.06 \%$ \\
\hline Ust-Lyzha & $\begin{array}{l}\text { rural } \\
(\text { selo })\end{array}$ & 402 & 16 & $3.98 \%$ \\
\hline Pechora & $\begin{array}{l}\text { urban } \\
\text { (gorod) }\end{array}$ & 58,100 & 40 & $0.07 \%$ \\
\hline Kadzherom & $\begin{array}{l}\text { rural } \\
\text { (poselok) }\end{array}$ & 2,369 & 28 & $1.18 \%$ \\
\hline Vuktyl & $\begin{array}{l}\text { urban } \\
\text { (gorod) }\end{array}$ & 18,600 & 33 & $0.18 \%$ \\
\hline Troitsko-Pechorsk & $\begin{array}{l}\text { urban (poselok } \\
\text { gorodskogo tipa) }\end{array}$ & 9,400 & 28 & $0.30 \%$ \\
\hline Yaksha & $\begin{array}{l}\text { rural } \\
(\text { selo })\end{array}$ & 1,445 & 22 & $1.52 \%$ \\
\hline
\end{tabular}

* Including the suburban settlement Iskatelei.

sults of this research and the other work packages of the SPICE Project have been published in Russian language (Kuhry, Ponomarev \& Habeck 2005). The survey examined people's perceptions of socio-economic and ecological problems in nine settlements of the Pechora Basin. The questionnaire included both multiple-choice and open-ended questions.

The settlements for this survey were selected according to the principle to investigate one urban and one rural settlement per district. Respondents were selected with a view to the settlement's major economic sectors and important enterprises. A total of 255 respondents took part in the survey. While the survey data may be considered roughly representative in terms of workplace, there is a certain bias in gender (women are over-represented) and education (individuals with higher education are over-represented).

The next section renders some of the survey findings, notably those pertinent to young people's views on how their families and communities have fared economically over the last decade. I present these findings here to corroborate the thesis of a growing feeling of stability in the early 2000 s, and the resulting possibility for making plans for one's future. This newly emerging trust in one's future, however, is strongly influenced by two factors: education and the place of residence. 


\section{LOCAL INHABITANTS' ASSESSMENTS OF THE SOCIO- ECONOMIC SITUATION IN THE PECHORA BASIN: AGE, EDUCATION AND REGIONAL FACTORS}

Respondents were asked to compare the economic situation of their community, and that of their family, at present (2002) in comparison with ten years ago. The different age cohorts' responses concerning the respondent's community are presented in Table 2, those concerning the respondent's family in Table 3. Generally, the younger the respondent, the more positively he/she assesses his/her community's situation as compared with ten years ago. The same is the case with the assessment of the respondent's family. Optimism clearly appears to be more widespread among young respondents than old ones. A third conclusion is that people tend to assess the situation of their family generally more positive than that of their community, which might be explained by a certain need for self-assertiveness or a higher commitment to solidarity within the family than the community.

Table 2. SPICE "Workpackage 2" survey. The economic situation of the respondent's community in 2002 as compared with ten years ago (results by age cohorts).

\begin{tabular}{|l|r||r|r|r|r|r|r|}
\hline Age cohort & $\begin{array}{l}\text { No. of } \\
\text { respon- } \\
\text { dents }\end{array}$ & "better" & $\begin{array}{l}\text { "better over } \\
\text { the last few } \\
\text { years" }\end{array}$ & $\begin{array}{l}\text { "on the } \\
\text { same level" }\end{array}$ & "worse" & $\begin{array}{l}\text { other } \\
\text { reply }\end{array}$ & $\begin{array}{l}\text { "don't } \\
\text { know" }\end{array}$ \\
\hline $\begin{array}{l}\text { Age } \\
51 \text { plus }\end{array}$ & 59 & $\mathbf{1 2} \%$ & $\mathbf{1 0} \%$ & $2 \%$ & $\mathbf{6 2 \%}$ & $\mathbf{1 2 \%}$ & $2 \%$ \\
\hline $\begin{array}{l}\text { Age } \\
\mathbf{4 1} \text { to } 50\end{array}$ & 83 & $\mathbf{1 9} \%$ & $2 \%$ & $0 \%$ & $\mathbf{4 7 \%}$ & $22 \%$ & $\mathbf{1 0 \%}$ \\
\hline $\begin{array}{l}\text { Age } \\
31 \text { to } 40\end{array}$ & 51 & $\mathbf{3 1 \%}$ & $\mathbf{1 0} \%$ & $2 \%$ & $\mathbf{4 5 \%}$ & $8 \%$ & $4 \%$ \\
\hline $\begin{array}{l}\text { Age } \\
\text { below } 31\end{array}$ & 62 & $\mathbf{4 7 \%}$ & $3 \%$ & $2 \%$ & $\mathbf{3 5 \%}$ & $3 \%$ & $\mathbf{1 0 \%}$ \\
\hline
\end{tabular}

Table 3. SPICE "Workpackage 2" survey. The economic situation of the respondent's family in 2002 as compared with ten years ago (results by age cohorts).

\begin{tabular}{|l|r||r|r|r|r|r|r|}
\hline Age cohort & $\begin{array}{l}\text { No. of } \\
\text { respon- } \\
\text { dents }\end{array}$ & "better" & $\begin{array}{l}\text { "better over } \\
\text { the last few } \\
\text { years" }\end{array}$ & $\begin{array}{l}\text { "on the } \\
\text { same level" }\end{array}$ & "worse" & $\begin{array}{l}\text { other } \\
\text { reply }\end{array}$ & $\begin{array}{l}\text { "don’t } \\
\text { know" }\end{array}$ \\
\hline $\begin{array}{l}\text { Age } \\
51 \text { plus }\end{array}$ & 59 & $\mathbf{2 7 \%}$ & $\mathbf{1 0} \%$ & $8 \%$ & $\mathbf{4 5} \%$ & $8 \%$ & $2 \%$ \\
\hline $\begin{array}{l}\text { Age } \\
41 \text { to } 50\end{array}$ & 83 & $\mathbf{2 9} \%$ & $4 \%$ & $\mathbf{1 1} \%$ & $\mathbf{3 6} \%$ & $6 \%$ & $\mathbf{1 4 \%}$ \\
\hline $\begin{array}{l}\text { Age } \\
31 \text { to } 40\end{array}$ & 51 & $\mathbf{4 1 \%}$ & $4 \%$ & $6 \%$ & $\mathbf{3 1 \%}$ & $10 \%$ & $8 \%$ \\
\hline $\begin{array}{l}\text { Age } \\
\text { below } 31\end{array}$ & 62 & $\mathbf{5 9} \%$ & $2 \%$ & $3 \%$ & $\mathbf{2 6} \%$ & $2 \%$ & $8 \%$ \\
\hline
\end{tabular}


In accordance with the aim of the 2004 Tartu conference "Generation P in the Tundra" to look at youth, I have sought to provide data for people at the age between 15 and 20 years. Unfortunately, the small number of respondents (24) of this age cohort does not permit to draw valid conclusions of statistical significance. Therefore it is not useful to single them out as an age cohort for quantitative purposes. However, we can look at these respondents more closely and find out what is characteristic of them, using qualitative data.

All of these 24 individuals are students at school (grades 10 or 11) or in higher education (college or university). It was more difficult to find people between 15 and 20 years of age (and willing to take part in the survey) in the rural communities than in the urban ones. In the streets of one community, Ust'-Lyzha, this age group was nearly invisible - it seemed as if they had all gone away. In fact, many of them have moved to town, either for higher education or a job.

Within the Pechora Basin, there are considerable regional disparities, not only of the rural/urban kind, but also in the north-south direction. The towns in the north (notably Nar'ian-Mar, Usinsk and Pechora) have economically benefited from the rapid development of oil and gas extraction. Further south, the towns of Vuktyl (gas extraction with dwindling gas reserves) and TroitskoPechorsk (timber industry) were in a state of stagnation or crisis in 2002. Rural communities suffer from the thorny restructuration of the agricultural sector. However, in comparison with many other regions of the Russian North, the villages surveyed in this study are in a technologically better position: they have all-year road connections to the district centre, electricity and telephone. Thus, their preconditions are different from those of such remote communities as Tuturi in Central Siberia (see Sántha 2009).

However, the all-year road connection also has an influence on the labour market and thus on the economic structure of the village. Ust'-Lyzha and many other villages around the town of Usinsk provide a striking example: it appears that out-migration of youth and young adults has affected the entire village over the last five years. While in the recent past, reindeer husbandry was a major sector of the local economy, by now many able-bodied persons, including indigenous ones, have started working in the oil industry. They usually work in two-week shifts and some of them now own a flat in the town, visiting their parents in the village once or twice per month. The villages are undergoing sub-urbanisation and rapid transformation of their economic profile. As one 25 years old woman from Ust'-Lyzha put it, "People leave the sovkhoz. They go to the oil companies, or to the job centre [to receive unemployment benefits]. That's more profitable." 
Regional economic disparities are mirrored by the replies of respondents across the Pechora Basin, as is manifest also in the replies to other questions of the survey ("When thinking of the economic situation of your family/of the place, what kind of development do you expect over the next ten years?" and "In summary of the above questions, how would you picture your future?"). Replying to these two questions, respondents from the age group between 15 and 20 wrote:

If the economic and ecological situation of the district stays the same without changes then it will lead to decline. (Troitsko-Pechorsk, female, 11th grade)

Personally, I look at the future with a certain degree of pessimism. Ten years is not so much time, after all. (Vuktyl, female, 11th grade)

I think that after grave shocks, people are ready to recover the losses and to improve their lives. I am confident that life in our region will improve. (Pechora, male, 11th grade)

To work in Usinsk is very profitable: many come here to earn money. I think that the economic situation of my family will improve as long as there is stable work and income. (Usinsk, female, 10th grade)

To some extent the above citations reflect the economic north-south disparity within the region. Respondents in the northern towns depending on oil extraction generally express more optimism concerning their own future, although they make it conditional upon economic stability, and they do not take stability for granted. Respondents from Nar'ian-Mar in the Nenets Autonomous Okrug write about rapid economic growth but also about unsustainable development, expecting that they will, or will need to, move away in some years:

The [Nenets Autonomous] Okrug will always remain a periphery, therefore it is not bad to work here for the first years [of one's career] with the aim of "initial accumulation of capital", but to connect one's future with the [Nenets Autonomous] Okrug is, in my opinion, not worthwhile. (Nar'ian-Mar, male, 11th grade)

Not a very promising [future], because the riches of the region are being sold out (idet razbazarivanie), and subsequent to the ecological decline comes the economic one. (Nar'ian-Mar, male, zoo-veterinary technical college)

Such responses exemplify that students generally differ in their optimism/ pessimism in accordance with the community in which they live. 
Put briefly, optimism appears to depend on place of residence, education and age. Young respondents assess the development more optimistically than older age groups. Many young people emphasise the importance of obtaining higher education in their personal lives. On these grounds, I would contend that youth generally do not perceive themselves as a "lost generation", while some of their parents do. For the predominant majority of young people, the future lies in the town or city. By the same token, the prospects for rural communities are more gloomy. Inhabitants of urban communities of all age groups show more optimism (or less pessimism) than their peers in rural communities, both in terms of the development over the last ten years as well as in terms of their predictions for the next ten years.

In the introduction I put forward the hypothesis that growing income directly leads to a more secure basis for planning one's future, and indirectly to a growing diversity of "sensible" ways of being. However, many anthropologists' long-term observations in indigenous communities of the Russian North point to the contrary: the main industrial sector responsible for Russia's economic upsurge - the oil and gas extraction - has a harmful impact on indigenous livelihoods, and traditional forms of land use in particular (see, for example, Dudeck 1996; Ludviksen 1995; Novikova 2000; Tuisku 1998 and several contributions to Kasten 2002). My research results in Komi reindeer-herding communities generally support the above observation, although I hold that environmental degradation is less detrimental to Komi reindeer husbandry than the economic and ideological position of the oil and gas industry (Habeck 2005). To illustrate the status of reindeer herding and its relations with fossil fuel extraction more closely, I shall talk about decisions about labour distribution and employment at individual and household level in reindeer-herding families.

\section{DOES IT MAKE SENSE TO WORK AS A REINDEER HERDER?}

While the previous section addresses the economic development and a certain optimism among youth expressed in survey data, this section deals with choices and constraints as experienced on both familial and individual level by people in one of the subregions of the survey, the villages around Usinsk. On the basis of my ethnographic work and acquaintance with Komi reindeer-herding families, I wish to discuss people's options to work in this particular occupation.

Let me start by briefly describing the different "trajectories" of two friends: Andrei and Andrei (Fig. 1, see next page). When I first got to know them in 


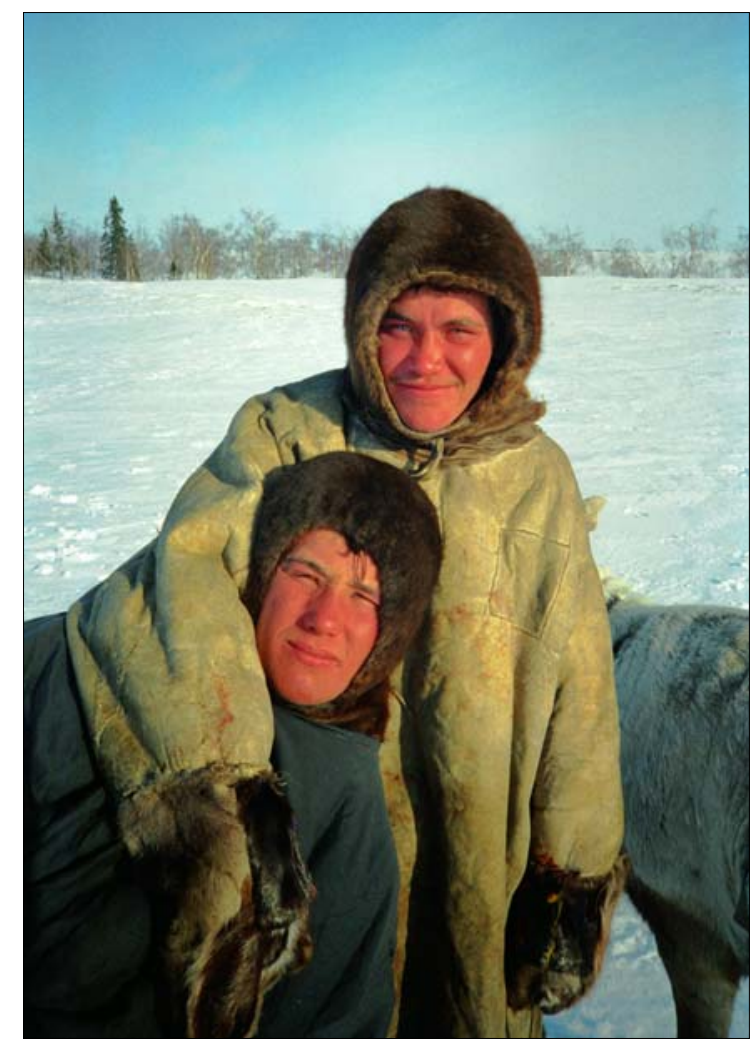

Figure 1. Andrei and Andrei, two young Komi reindeer herders. (C) Joachim Otto Habeck, spring 1998.

early 1999, both were 16 years old and worked in the same reindeer herding team. One of them is from Ust'-Lyzha, the other from a village between Ust'Lyzha and the district town Usinsk. Both were experienced herdsmen, considering their age, and were mentally preparing to leave their communities to do their army service. Both had rather ambivalent feelings about the presence of oil workers in the tundra. One of them - the one from Ust'-Lyzha - explained me that it is a "dirty job" (chernaia rabota), and hence not attractive. In 2002, when they had returned from the army, one Andrei resumed his work as reindeer herder, while the other one - the one from Ust'-Lyzha - preferred to hang around. It was the mayor of his home community who eventually helped him to find a short-term job with one oil company, and when I revisited the region in 2005 he was still employed in this sector, albeit at a different company. In the meantime, other young herdsmen from these villages had also found work in the oil industry, while the reindeer-herding enterprise had been amalgamated with another one, which was accompanied by reductions in the number 
of reindeer herding teams and staff. Andrei the herder has meanwhile attained the status as head of team (brigadir).

Throughout the 1990s, the families in the villages around Usinsk were forced to make a living by combining multiple sources of income, both monetary and non-monetary. The diversification of household income provided access to different resources and thus a certain security in times of unpredictable economic development. The reindeer herders' families engaged not only in reindeer herding: some family members worked in the local shops or services (firemen, technicians), elderly family members added to the household income with their state pensions, every family grew their own potatoes and vegetables. Some reindeer-herding families also kept a cow, while those who did not nonetheless participated in the collective hay-making because they received milk in return for their commitment. The families had to come to certain decisions about who does what kind of job, in accordance with the household's needs, the assets and opportunities available, the parents' expectations, and of course the children's predispositions and talents.

The decision of a young person to work in the reindeer-herding camp meant considerable even if not quite reliable income of meat (which was often more important than the actual pay by the sovkhoz), but also the absence of this person for nine months per year from the village "base", and the family's obligation to provide the necessary equipment for life in the tent. The decision of a young man to work as technician was likely to result in other assets, including access to certain material resources, but also reduced the household's available workforce for reindeer husbandry. There is a higher number of men than women working in reindeer herding, owing to the composition of work teams (per team ideally six to eight men as herders, pastukhi, and one or two women as tent workers, chum-rabotnitsy). At the same time, reindeer herding as an activity is more attractive to men than it is to women. By the late 1990s, almost none of the young women I spoke to wanted to work in reindeer husbandry but envisaged finding a job in the village or, even better, in the town. To marry somebody from outside the village was, and is, more widespread among young women than young men. As a side effect, there is a comparatively high number of bachelors in the village - a phenomenon known from many other regions of the Russian North (Kwon 1997; Schindler 1997; SsorinChaikov 2003).

By mid-2005, the number of young men employed by oil companies had increased, and the importance of subsistence economy had slightly decreased. The reindeer-herding family that I had known for many years ceased to participate in the collective hay-making. "We buy milk in the shop, why should we help make hay?" the husband of one of the family's daughters said. It appears 
that the monetary income has become reliable enough to reduce the diversity of economic activities. However, the family's engagement in reindeer husbandry continues (one son has married and the couple live with their baby in the tent for most of the year, and a second son is likely to resume his work as herder after his return from the army). For the family, economically it does make sense to have somebody work in the tundra, even though wages in the oil industry are much higher. It is not the wages that are the main benefit from the family's engagement in reindeer herding but rather the meat from the privately owned reindeer, which are kept along with the collective (sovkhoz) ones.

During my fieldwork, I have sought to find out who wants to work in reindeer herding, for what reasons, and who is able and eligible to work in reindeer herding. Discussing these questions in the context of a different region (an Eveny community in the Republic of Sakha-Yakutia), Vitebsky and Wolfe observe that herders do their work "partly because someone still has to, partly because some of them like the sense of freedom, and partly because they do not have anywhere else to go" (2001: 82). In the Komi case, the economic performance of reindeer husbandry is better than in Sakha-Yakutia and thus the statement "someone still has to", in my opinion, is too pessimistic to be applied to the Komi case. Instead, I would add, as a third factor, ability and skill: Komi herders do their work partly because they have acquired the knowhow to do it, while others have not.

Both willingness and ability to work as a herder can be addressed from the perspective of education, pedagogy, and the valorisation of different kinds of knowledge and skills. While it is true that a comparatively high number of young herdsmen are school dropouts and thus hardly have anywhere else to go, the bodily skills and experience they acquire during their time in the tundra enables them to make a living in an environment where hardly anyone else can succeed, or even survive. For this reason, other people in the villages look at them with a mixture of disrespect and admiration. The knowledge taught at school cannot provide the basis for living in the tundra. There is a distinction between 'school pedagogy' and 'tundra pedagogy', which differ in the ways of knowing, the value of knowledge and the mode of instruction (cf. Anderson 2000).

The ability to live in a sphere where others would easily fail also accounts for the sense of freedom. For most of the year, reindeer herders operate outside the ambit controlled by the bosses of the reindeer-herding enterprises, and more generally, outside the ambit of social control characteristic of the village. As Fondahl (1998) describes, in some cases young individuals from the village start working as herdsmen with the explicit aim to achieve personal 
rehabilitation after a period of "hanging-around" or criminal behaviour. Their input into a useful, productive activity gives a new sense to their lives.

Returning to the concept of sense, then, different spaces "make sense" in different ways. According to their ideal content, they can be described as follows:

- The sense of living in the tundra (or forest) as a reindeer herder (or similarly, as a hunter or fisher) lies in the freedom that this space provides, the comparatively low degree of social control, a feeling of purity, and the ability to live close to "nature" with one's specific skills and experience.

- The sense of living in the village is defined by the close ties within kinbased and other social networks, the principle of mutual help and social solidarity.

- The sense of living in a city is constituted by social mobility, higher education and a good job, and also the diversity and amenities of what is often called a "cultured" (kul'turnoe) life (cf. Habeck 2006).

\section{THE LURE OF THE CITY}

The survey that I conducted in the Pechora Basin in 2002 shows many parallels and similarities with the findings of the youth survey in Novosibirsk and Novosibirskaia Oblast' by Glendinning, Pak and Popkov (2004). This study was carried out in 2001-2002 among 700 respondents at 14-15 years of age. Some of its results shall be described here since they contribute to our understanding of how young people assess their own situation and their future prospects.

Higher education is of key importance for young people in both the city and the rural areas around Novosibirsk. It is seen not as a purpose unto itself but as a precondition for employment and material stability of one's family in the future. As Glendinning, Pak and Popkov note, "[t]he notion of education is tightly bound in the interview data to the idea of securing good employment as a prerequisite to guarantees of stability and security, related to conceptions of a 'normal life"' (2004: 40). Moving to the city is necessary in order to get higher education. "[A] major concern for the rural household is financial arrangements for the further education of student-age children" (Glendinning, Pak \& Popkov 2004: 37).

Work in the agricultural sector has very low status: most young people in the rural communities prefer to be unemployed over finding a job as milkmaid or tractor driver (Glendinning, Pak \& Popkov 2004: 40). Here we can discern the same phenomenon, as reported above from Ust'-Lyzha. It appears that 
agriculture in general is a sphere for those who do not have anywhere else to go. Higher education is the most crucial asset for those who wish to leave the place.

Moreover, the three authors found that for city youth, it is most important to live in a place that is perceived as "progressive" and dynamic:

For youth in the city, a rural lifestyle is perceived as boring and associated with drudgery and menial tasks; life is seen as hard, unpleasant and 'backward' and incompatible with the pursuit of a career and 'modern' lifestyle. (Glendinning, Pak \& Popkov 2004: 41)

Notwithstanding the observation that for different individuals, life in the tundra and life in the village can be as "sensible" as life in the city (see previous section), life in the city is commonly seen as most prestigious. The economic, political and discursive hegemony of the city over the countryside is clearly evident in Russia. "Cultured" (kul'turnoe) existence is urban existence. There is a conceptual progression from the "uncivilised" to the "civilised" mapped out across space, with the tundra representing one end and the city, the other (Habeck 2005; Kwon 1997; Vitebsky \& Wolfe 2001). Moving to the city is attractive, but has a certain cost not only in monetary terms but also in social ones. Leaving behind the established social networks of the village community, rural youth enter a dynamic yet equally unreliable space.

Rural youth feel that social problems, such as drugs and crime, are characteristic of city life, and when speaking about the idea of moving, their first preference would be to move to a 'small' city, if possible. The 'big' city, i.e. Novosibirsk, is seen as a place of opportunities, but also as a dangerous and risky place. (Glendinning, Pak \& Popkov 2004: 41-42)

Drawing on preliminary findings from my fieldwork in the city of Novosibirsk, I would hold that young people in the city are less concerned about drugs and crime than the rural youths whose opinions are quoted above. Petty criminality continues to be a problem whereas mafia activities seem less relevant now than ten years ago; they are said to be limited to certain suburbs. Furthermore, patterns of drug consumption are changing. One young informant pointed out that the first wave of hard drug consumption has recently abated as many youth have been confronted with the death of a peer or friend owing to drug abuse.

Among my ten respondents born between 1979 and 1985, the majority thinks that the visible presence of gopniki (which may be defined as dim-witted, potentially aggressive youth) in the streets of Novosibirsk has diminished over the last five or so years. Their statements also point to a growing diversifica- 
tion of "subcultures": the category of neformaly (non-conformists), under which different styles of oppositional attitudes and attires were subsumed in the $1980 \mathrm{~s}$, is becoming obsolete as these different styles (for example, punk, hippie, skin, or gothic) have increasingly ramified and now lead their own existence (Pilkington et al. 2002: 106). The growing diversity of lifestyles is being met with tolerance at least in the city centre of Novosibirsk. In other words, people now have less fear of getting beaten for unusual outer appearance than in the 1990s. Even though certain groups continue to despise each other, open aggression is giving way to co-existence.

While these observations are preliminary and may be representative only for young people from well-off families, they do support the argument that for many people in Russia, life makes more sense now than it did ten years ago: in addition to an upward tendency in the national economy and smaller or larger improvements in most households' income, I also see a slightly more secure basis for tolerance within Russian society and hence the possibility to lead one's life according to one's personal predilections. People at the age of 20 definitely have a larger range of options for defining in which ways their life makes sense than the generation of their parents had when they were young.

For many individuals, however, the range of choices is limited by the amount of money available. As some lifestyles (e.g., biker) require considerable material input, the diversity of lifestyles appears to depend, to some extent at least, on the concentration of affluent people. There are also some lifestyles directly connected with conspicuous consumption. In Novosibirsk, this phenomenon is represented by a group of young people called mazhory, who show off their cars and clothes along the main high-street and on the central squares of the city.

\section{CONCLUSION}

While most inhabitants of the Russian Federation remember the 1990s as a period of "mess" (bezobrazie), the early 2000s are commonly being associated with economic growth, more reliable household income and a higher degree of "stability" in general.

One may assume that this perception of the overall economic situation translates into more trust in one's own future and more scope for realising one's plans. I have sought to explore to what extent, and in which ways, the political idea of "stability" articulates with young people's expectations about their future and their (possibly existing) life projects. The basis for this exploration was a twofold hypothesis: on the one hand, an economically more stable situation creates better preconditions for planning one's career and future; on the 
other, a general growth of income throughout all parts of a society leads to a reduction of conflicts and aggression within the society, to more tolerance and thus, to a larger scope for following one's personal interests and expressing a personal identity. The ethnographic and survey data presented here serve to corroborate the initial validity of this twofold hypothesis, even though it needs to be scrutinised and modified.

Notwithstanding the generally optimistic inventory presented here, the various findings unanimously point to a number of negative developments, notably the growing disparity between the city and the countryside, with the probable outcome that many of the remoter rural communities will gradually turn into seasonal settlements or simply cease to exist. The discrepancy between incomes in agriculture and other sectors (notably, mineral resource extraction) makes employment in the village less and less attractive. At the same time, we have seen that a well-paid job and a reliable growth in the household's financial income make auxiliary economic activities, such as keeping a cow or growing potatoes, more and more obsolete. For the same reason, reindeer herding as an auxiliary activity has become less and less attractive, and a dwindling number of people (in the north of the Komi Republic) are engaged in it. However, I venture to predict that it will continue to exist as an economic activity carried out by a small number of specialists, and it will also continue to exist as a way of life because it provides an alternative to the commonplace migration to the city.

Social stratification affects not only the relations between urban and rural inhabitants; of course, it also appears within the cities themselves. Owing to low income, a large portion of the population of Novosibirsk is still unable to lead a "normal" life (or, in terms of formulating a goal or life project, a "sensible" life). Inasmuch as many leisure-time activities and lifestyles are dependent on certain patterns of consumption, they are not attainable for large parts of society. The diversity of lifestyles and identities has clearly been growing over the last twenty years, yet it is partly conditional upon the income situation of the individual and the household. Clearly, these observations deserve to be discussed in the broader context of social exclusion and possibly existing tendencies towards individualism among youth (concerning Siberia, see Anderson 2004; Glendinning, Pak \& Popkov 2004), but in this article such an attempt would be premature, owing to the fact that more research is underway (Habeck 2008).

When directly asked, some of my Novosibirsk respondents made it clear that the favourable situation of the early 2000 s does not mean that they feel more confident when making plans for the future, because sudden political 
and/or economic changes cannot be excluded. As one woman in her thirties put it, she and her friends rarely relax but work hard in order to accomplish material wealth (a flat, a car, etc.) now, to have at least some assets in case of a new monetary crisis, as the one in August 1998. Making plans appears to be easier now than it was ten years ago, but the outcome is still conditional on numerous imponderables, and this is why the country's economic upsurge does not immediately translate into a person's growing confidence in his or her future.

Finally, despite the growing tolerance towards a diversity of lifestyles, I also see contradictory tendencies. The current government of Russia actively promotes patriotism and patriotic education. The mass media and many other spheres of society are subject to growing militarism (cf. Gushchina 2004). News reports and security announcements in public places create a constant atmosphere of threat, with the implicit statement that society needs to be monitored, guarded and defended. As in other countries, in Russia state authorities require the citizens to follow a certain discipline. But this requirement is not so much grounded on the prerogative of a civil society with its pragmatic emphasis on a respectful attitude towards other citizens, but rather on the prerogative of the "Homeland" (Rodina) that ought to be loved. The citizen's good behaviour is necessary for the sake of an abstract whole rather than for the immediate environment. I interpret the growing influence of patriotism as a measure of the state authorities, speaking in the name of the Homeland, to make its citizens, the children, express their solidarity to the family. They should also accept the educational role of the State (cf. Khlinovskaya-Rockhill 2004). From a somewhat different angle, the state-instigated patriotism is an attempt at (re-)establishing moral values (moral'nye tsennosti) after a decade of mess (bezobrazie), when virtually all principles of social co-existence were put under question. Of course, the state-promoted restoration of moral values has a strong influence on how individuals make sense of their lives.

\section{ACKNOWLEDGEMENTS}

Since the presentation of this paper at the conference "Generation $\mathrm{P}$ in the Tundra" in Tartu in October 2004, it has been further developed, the main modification being the inclusion of new fieldwork materials from summer 2005. I am grateful for the comments of Chris Hann, Anthony Glendinning and anonymous reviewers, who helped to further improve this paper. 


\section{NOTES}

1 The TUNDRA project was supported by the Environment and Climate Programme of the European Commission (Contract No. ENV4-CT97-0522), Climatology and Natural Hazards. See Kuhry and Holm (1999).

2 The SPICE project is supported by the INCO-Copernicus 2 Programme of the 5th Framework of the European Commission (Contract No. ICA2-CT-2000-10018). See Kuhry and Soppela (2002).

\section{REFERENCES}

Anderson, David G. 2000. Identity and Ecology in Arctic Siberia: The Number One Reindeer Brigade. Oxford: Oxford University Press.

Anderson, David G. 2004. 'Everything is Still Before You': The Irony of Youth Discourse in Siberia. Sibirica. Vol. 4, No. 1, pp. 14-30.

Dudeck [Dudekk], Stephan 1996. Nekotorye soobrazheniia k perspektivam traditsionnogo prirodopol'zovaniia korennykh narodov Zapadnoi Sibiri. [On the Perspectives of Traditional Resource Use of the Native People in Western Siberia.] In: E. Kasten \& Y.V. Dul'chenko (eds.) Resursy traditsionnogo prirodopol'zovaniia narodov Severa i Dal'nego Vostoka Rossii. Petropavlovsk-Kamchatskii: Kamshat, pp. $123-130$.

Fondahl, Gail A. 1998. Gaining Ground? Evenkis, Land, and Reform in Southeastern Siberia. Boston [etc.]: Allyn and Bacon.

Glendinning, Anthony; Pak, Ol'ga \& Popkov, Yurii V. 2004. Youth, Community Life and Well-being in Rural Areas of Siberia”. Sibirica. Vol. 4, No. 1, pp. 31-48.

Gushchina, V. N. 2004. Tendentsii arkhaizatsii dominiruiushchego tipa muzhestvennosti v rossiiskom obshchestve. [Tendencies of Archaization in the Dominant Type of Masculinity in the Russian Society.] In: D.V. Gromov et al. (eds.) "Muzhskoe" $v$ kul'turnom kontekste goroda: materialy nauchnoi konferentsii (SPb., 2224 aprelia 2004 g.) Moskva: Institut Etnologii i Antropologii im. N. N. Mikliukho-Maklaia; Sankt-Peterburg, p. 18.

Habeck, Joachim Otto 2005. What It Means to Be a Herdsman: The Practice and Image of Reindeer Husbandry among the Komi of Northern Russia. Münster [etc.]: LIT Verlag.

Habeck, Joachim Otto [Khabek, I. O.] 2006. Gender, 'kul'tura', severnye prostory. [Gender, 'Kul'tura', and Northern Expanses.] Etnograficheskoe obozrenie. Vol. 4, pp. 59-68.

Habeck, Joachim Otto 2008. Conditions and Limitations of Lifestyle Plurality in Siberia: A Research Programme. Max Planck Institute for Social Anthropology Working Paper Series, 104. Available online at http://www.eth.mpg.de/pubs/wps/mpieth-working-paper-0104.html, last accessed on 1 March 2009.

Kasten, Erich (ed.) 2002. People and the Land: Pathways to Reform in Post-Soviet Siberia. Berlin: Reimer. 
Khlinovskaya-Rockhill, Elena 2004. Social Orphans and Neblagopoluchnaia Family: The Cycle of Child Displacement in the Russian Far East. Sibirica. Vol. 4, No. 2, pp. 132-149.

Kuhry, Peter \& Holm, Tuija 1999. Arctic Feedbacks to Global Warming: Tundra Degradation in the Russian Arctic (TUNDRA). Available online at http:// www.ulapland.fi/home/arktinen/tundra/tundra.htm, last accessed on 1 March 2009.

Kuhry, Peter \& Soppela, Päivi 2000. Sustainable Development of the Pechora Region in a Changing Environment and Society (SPICE) 2000-2003. Available online at http://www.ulapland.fi/home/arktinen/spice/spice.htm, last accessed on 1 March 2009.

Kuhry [Kuri], Peter; Ponomarev, Vasilii \& Habeck, Joachim Otto (eds.) 2005. Ustoichivoe razvitie Pechorskogo regiona v izmeniaiushchikhsia usloviiakh prirody i obshchestva. [Sustainable Development of the Pechora Region under Changing Natural and Social Conditions.] Syktyvkar: Institut Biologii Komi Nauchnogo Tsentra Ural'skogo Otdeleniia RAN.

Kwon, Heonik 1997. Movements and Transgressions: Human Landscape in Northeastern Sakhalin. In: S.A. Mousalimas (ed.) Arctic Ecology and Identity. Fullerton, CA \& Budapest: International Society for Trans-Oceanic Research, pp. 143169.

Ludviksen [Jernsletten], Johnny-Leo 1995. Oil, Gas and Reindeer Herding in the Nenets Autonomous Okrug. In: I. Bjørklund, J.J. Møller \& P.K. Reymert (eds.) The Barents Region. Tromsø: Tromsø Museum, pp. 63-70.

Novikova, Natalia I. 2000. Ot chuma na tsentral'noi ploshchadi do suda. [From the Tent on the Central Square to the Court.] In: O. A. Muraskho (ed.) Severnye narody Rossii na puti $v$ novoe tysiacheletie. [Northern Peoples of the Russian North on a Way to New Millennium.] Moskva: Assotsiatsiia korennykh malochislennykh narodov Severa, Sibiri i Dal'nego Vostoka Rossiiskoi Federatsii, pp. 150-157.

Omel'chenko, Elena 2002. Izuchaia gomofobiiu: mekhanizmy iskliucheniia 'drugoi' seksual'nosti v provintsial'noi molodezhnoi srede. [Studying Homophoby: Mechanisms of Exclusions of the 'Other' Sexuality among Provincial Youth.] In: Y. Zdravomyslova \& A. Temkina (eds.) V poiskakh seksual'nosti. Sankt-Peterburg: Dmitrii Bulanin, pp. 469-508.

Pilkington, Hilary 1994. Russia's Youth and Its Culture: A Nation's Constructors and Constructed. London \& New York: Routledge.

Pilkington, Hilary; Omel'chenko, Elena; Flynn, Moya; Bliudina, Ul'iana \& Starkova, Elena 2002. Looking West? Cultural Globalization and Russian Youth Cultures. University Park: Pennsylvania State University Press.

Sántha, István 2009. "Bright Future": Knowledge, Practices and Strategies among the Young People in a South Siberian Evenki Village. Folklore: Electronic Journal of Folklore. Vol. 41, pp. 163-188.

Schindler, Debra L. 1997. Redefining Tradition and Renegotiating Ethnicity in Native Russia. Arctic Anthropology. Vol. 34, No. 1, pp. 194-211.

Ssorin-Chaikov, Nikolai 2003. A Social Life of the State in Subarctic Siberia. Stanford, CA: Stanford University Press. 
Tuisku, Tuula 1998. Reindeer Herding: Collectivization and Oil and Gas Exploitation (A Case Study of Nenets Reindeer Herding). In: G. Duhaime, R. O. Rasmussen and R. Comtois (eds.) Sustainable Development in the North: Local Initiatives vs. Megaprojects. Circumpolar Arctic Social Sciences PHD Network. Proceedings of the Second Conference. Québec: Gétic, Université Laval, pp. 149-160.

Vitebsky, Piers \& Wolfe, Sally 2001. The Separation of the Sexes among Siberian Reindeer Herders. In: A. Low \& S. Tremayne (eds.) Sacred Custodians of the Earth? Women, Spirituality, and the Environment. Oxford: Berghahn Books, pp. 81-94. 